\title{
Citizens' ACCEPTANCE OF E-GOVERNMENT SERVICES
}

\author{
Yasemin Çetin-Kaya ${ }^{1}$ and Mahir Kaya ${ }^{2}$ \\ ${ }^{1 \& 2}$ Department of Computer Engineering, Gaziosmanpasa University, Tokat, Turkey
}

\begin{abstract}
The rate of computer and internet usage has been increasing rapidly around the world. In parallel with the technologic developments in computer science, transformation from traditional services to online services has gained speed. The aim of this study is to predict the factors that affect e-government service usage. A research model is developed to achieve this aim. The proposed model bases on Technology Acceptance Model and Theory of Planned Behaviour. A questionnaire is developed to evaluate the model. This questionnaire composes of two parts: demographics part and item part. In the items part, 32 items comprising the factors of the proposed model are asked to participants. 100 participants fill the questionnaire. Reliability analysis of the questionnaire is evaluated with internal consistency reliability method. Results show that all items satisfies the reliability conditions. The reliability of whole questionnaire Cronbach Alpha is 0.885. The Cronbach's alpha for the overall scale of each of the factors ranges from 0.878 to 0.890. Regression analysis results showed that all hypotheses are supported. This study provides some valuable references to understand citizens' acceptance level of e-government services.
\end{abstract}

\section{KEYWORDS}

E-government, Technology acceptance, Online services \& Internet usage.

\section{INTRODUCTION}

E-government is defined as "the application of information and communications technology (ICT) to transform the efficiency, effectiveness, transparency and accountability of informational and transactional exchanges within government, between governments and government agencies at federal, municipal and local levels, citizens and businesses; and to empower citizens through access and use of information" [1].

E-Government infrastructure is a combination of legal, technical, knowledge and administrative policy that are critical for the success of the e-government applications [2]. It composes of two dimensions: legal infrastructure such as knowledge acquisition and e-signature law, and technological infrastructure such as number of computers and internet users. Transformation towards the e-government is a process and do not accrue instantly. Four main steps are advised for successful transformation: They are position identification, vision creation, strategy formulation, and priority and effect determination [2]. Moreover, this process continually renews and improves itself.

The use of technology is decisive for users' attitudes towards information technology. Before transforming from traditional services to electronic services, government agencies should identify factors that affect citizens' behaviour on online services. 
There are several models that analyze the technological evolution acceptance in the literature. The Technology Acceptance Model (TAM), is a known model for assessing attitudes toward information technology, developed by Davis [3]. Another model is the Unified Theory of Acceptance and Use of Technology (UTAUT). This theory has been developed by Venkatesh, Morris and Davis, with the review of the current technology acceptance literature [4]. Diffusion of Innovation (DOI) has been developed for acceptance of innovation rather than technology acceptance and bases on sociology [5]. While determining the acceptance of certain technological products or applications such as e-government services or e-learning. these models are taken as a basis. Then, some domain-specific dimensions can be added to the model.

In recent years, a great amount of study has been performed to clarify which constructs affect users' technology acceptance. Results showed that perceived usefulness [6,7] and perceived ease of use $[6,8]$ positively correlated with attitudes towards using e-government. Risk is another dimension that affects the peoples' behavioural intention about e-government usage [7,9]. Subjective Norms that means influence of the other people and media on the e-government acceptance is significantly affected the citizen's attitude $[6,7,10]$. Individual factors such as gender and age were also examined $[8,11]$.

Despite the fact that many research investigates the users' online service acceptance, the process of e-government service acceptance is not understood clearly enough. While information technology offers high performance and efficiency for users, many systems are not used appropriately and adequately because of the users' adoption problems such as unawareness. Unless a system is used, it does not provide any benefit to the user [12]. Accordingly, the aim of this research is to clarify the attitudes of citizens towards e-Government usage.

\section{MATERIALS AND MethodS}

\subsection{Problem Definition}

With the enhancement in the ICT, governments offer more electronic services to the citizens. Acceptance and use of e-government applications become a vital area and models have been developed to predict and analysis the adoption of the technology. Generally, researchers choose one model and add new constructs to it. This give rises to great amount of models that investigate the attitude of the people to the technology in e-government domain.

It is shown that there is a need to develop a new framework that contains the domain specific dimensions for e-government adaption. This new framework should include the most effective constructs of the main models; TAM, UTAUT, Theory of Reasoned Action (TRA) and Theory of Planned Behaviour (TPB) [13].

The aim of this study is to develop a model that investigated the e-government service acceptance. In order to understand the behaviour of citizens a questionnaire is designed based on this model.

\subsection{Model DeVelopMent}

A literature survey was conducted to gain information about the current e-government technology acceptance the research in the world. The most frequently used constructs were identified. The results of this analyze aided to set our research model. The proposed research model is based on 
TAM and TPB. Moreover, external variables are included to the model. E-Government is a sociotechnical term therefore the constructs of the proposed model were determined under two main dimensions; sociological and technical. Sociological constructs are Social Influence (SI), External Influence (EI), Perceived Usefulness (PU), Perceived Behavioural Control (PBC) and Trust to Government (TRG). Technical constructs are Computer Self Efficacy (CSE), Perceived Ease of Use (PEOU) and Perceived Risk (PR). The proposed model is given in Figure 1.

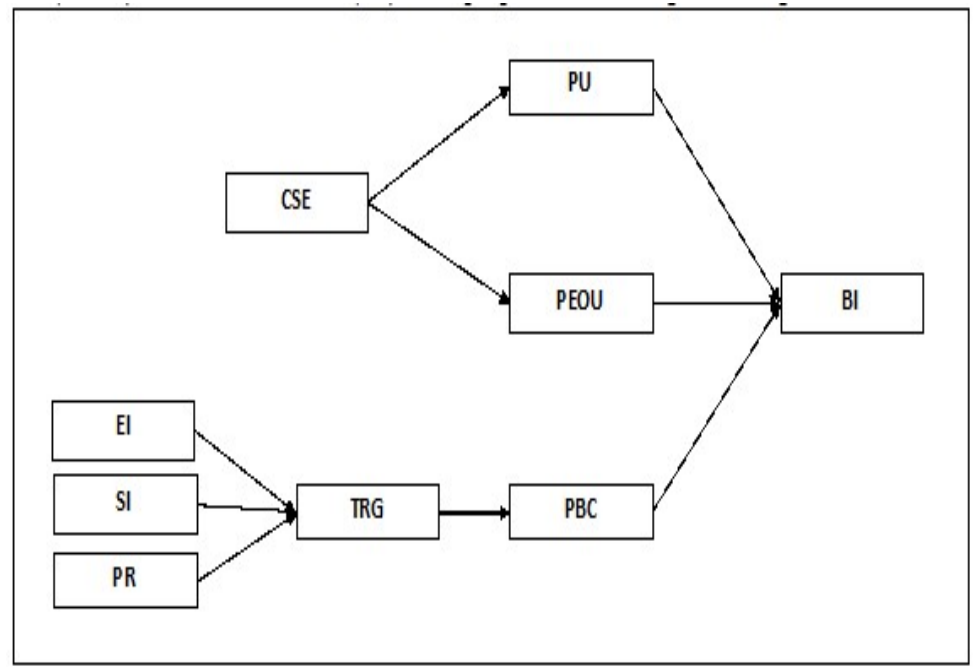

Figure.1. Proposed Research Model

\subsection{HYPOTHESIS DEVELOPMENT}

The hypothesizes were developed in accordance with the proposed model. They are listed below. H1. The Perceived Usefulness positively affects the users' intention to use the e-government web sites.

H2. The Perceived Ease of Use positively affects the users' intention to use the e-government web sites.

H3. The Perceived Behavioral Control positively affects the users' intention to use the egovernment web sites.

H4. The Computer Self Efficacy positively affects the Perceived Usefulness of using the egovernment web sites.

H5. The Computer Self Efficacy positively affects the Perceived Ease of Use of using the egovernment web sites.

H6. The Trust to Government positively affects the Perceived Behavioral Control of using the egovernment web sites.

H7. External Influence positively affects the Trust to Government of using the e-government web sites.

H8. The Social Influence positively affects the Trust to Government of using the e-government web sites.

H9. The Perceived Risk negatively affects the Trust to Government of using the e-government web sites. 


\subsection{QUESTIONNAIRE DEVELOPMENT}

The questionnaire starts with the demographic questions. The gender, age, education levels, work information, computer and internet usage and e-government experiences of the subjects are collected. Then, questions that are related with e-government service acceptance were prepared. The questionnaire composes of 32 items: BI ( 3 items), CSE (4 items), EI (3 items), PBC (3 items), PEOU (4 items), PR (4 items), PU (4 items), SI (3 items), TRG (4 items), (see Appendix). The items were adapted from the previous works in technology acceptance domain. The six point Likert scale was used to collect answers of the questionnaire (1-strongly disagree to 6-Strongly agree).

The questionnaire was designed to deliver in electronic form. This format provides us to achieve more people. Therefore, results of this study are more accurate by increasing number of answers. Moreover, electronic format reduces the analysis time of the questionnaire.

The questionnaire was prepared with the C\#.net language. It was designed with blue and white color which does not divert user attention. The questions and answer choices have different color to facilitate tracking. The radio button is used for one-choice-questions. It is not allowed to select two choices in the same questions. On the other hand, for some questions, users can select one or more choices. These types of questions are designed with the check box. There is a "Send the Form" button and it is not allowed to send form without answering all questions. The warning message window is displayed and gives notice to user filling all questions. After answered all questions and send the form, the user is directed a new page and congratulations message is displayed.

Questionnaire was conducted to people above 18 years. The questionnaire was distributed to the people with different age, different education level and different technological background. 100 participant filled the questionnaire.

\section{RESULTS AND DISCUSSION}

\subsection{DEMOGRAPHICS}

The questionnaire contains 11 demographic questions. These questions serve the purposes to see how closely the sample replicates the known population. The more closely the demographic distribution of survey respondents matches the population, the more confidence data is obtained. Using demographic questions also allow us to compare results between particular groups of respondents. The demographic questions were analysed one by one that described below:

Table 1. Gender distribution

\begin{tabular}{|c|c|}
\hline Sex & Percentage of Participants \\
\hline Female & 48 \\
\hline Male & 52 \\
\hline
\end{tabular}

Table 2. Age distribution

\begin{tabular}{|c|c|}
\hline Age & Percentage of Participants \\
\hline $18-20$ & 12 \\
\hline $21-30$ & 66 \\
\hline $31-40$ & 13 \\
\hline $41-50$ & 9 \\
\hline
\end{tabular}


Table 3. Education Level

\begin{tabular}{|c|c|}
\hline Education Level & Percentage of Participants \\
\hline Primary School & 6 \\
\hline Secondary School & 3 \\
\hline High School & 18 \\
\hline University & 49 \\
\hline Ms Degree & 18 \\
\hline Phd Degree & 6 \\
\hline
\end{tabular}

Table 4. Job distribution

\begin{tabular}{|c|c|}
\hline Job Title & Percentage of Participants \\
\hline Civil Servant & 13 \\
\hline Private Sector & 51 \\
\hline Retired & 5 \\
\hline Self-Employment & 4 \\
\hline Student & 18 \\
\hline House Wife & 1 \\
\hline Not working & 8 \\
\hline
\end{tabular}

Table 5. Computer usage

\begin{tabular}{|c|c|}
\hline Experience & Percentage of Participants \\
\hline$<1$ year & 5 \\
\hline $1-3$ years & 12 \\
\hline $4-6$ years & 14 \\
\hline $7-9$ years & 25 \\
\hline$>10$ years & 44 \\
\hline
\end{tabular}

Table 6. Internet usage

\begin{tabular}{|c|c|}
\hline Experience & Percentage of Participants \\
\hline$<1$ year & 11 \\
\hline $1-3$ years & 8 \\
\hline 4-6 years & 24 \\
\hline 7-9 years & 34 \\
\hline$>10$ years & 23 \\
\hline
\end{tabular}

Table 7. E-government website usage

\begin{tabular}{|c|c|}
\hline Experience & Percentage of Participants \\
\hline$<1$ year & 5 \\
\hline $1-3$ years & 12 \\
\hline $4-6$ years & 14 \\
\hline $7-9$ years & 25 \\
\hline$>10$ years & 44 \\
\hline
\end{tabular}


Table 8. E-government usage purposes

\begin{tabular}{|c|c|}
\hline Purpose & Number of Participants \\
\hline To get information & 86 \\
\hline To download application form and documents & 63 \\
\hline $\begin{array}{c}\text { To perform government agencies related jobs } \\
\text { online }\end{array}$ & 41 \\
\hline
\end{tabular}

Table 9. E-government application

\begin{tabular}{|c|c|}
\hline Application & Number of Participants \\
\hline Scholarship Transactions & 62 \\
\hline Voter Information & 66 \\
\hline Registered Shipment & 49 \\
\hline Passport Transactions & 34 \\
\hline Exam Result Transactions & 71 \\
\hline Social Security Transactions & 46 \\
\hline Motor Vehicle Transactions & 39 \\
\hline Court Transactions & 7 \\
\hline Tax Transactions & 22 \\
\hline Military Service & 20 \\
\hline Address Registration Procedures & 27 \\
\hline Culture and Art Activities & 36 \\
\hline Municipality Transactions & 15 \\
\hline
\end{tabular}

To sum up the demographic information, 100 responders participated to the study. Approximately, gender distribution is equal. The vast majority of participants were between the ages of 21-30. About $\% 65$ of the participants graduated from university. Most of the participants work in private sector. Also, most of them have familiar with the internet and computer for seven years or above. Moreover, the awareness of the e-government website is very high. Most of people have used e-government website for a long time. The people use e-government application for the purpose of getting information, downloading application form and documents, and performing government agencies related jobs online.

\subsection{RELIABILITY ANALYSIS}

Reliability means that "the degrees to which individual's deviation scores, or z-scores, remain relatively consistent over repeated administration of the same test or alternate test form" [14]. There are many ways for testing reliability such as parallel forms and test-retest reliability. The internal consistency reliability was chosen. This form of reliability is used to judge the consistency of results across items on the same test. The Cronbach Alpha values of the items were calculated. Reliability tests of the questionnaire were done via PASW.

The reliability test was conducted to ensure the consistency or stability of the items [15]. The Cronbach alpha coefficients range between 0 and 1 was used to analyse the reliability of the instruments and Cronbach Alpha less than 0.5 is not acceptable [15]. First, the whole test reliability was analysed. Table 10 displays the reliability of whole questionnaire. Cronbach Alpha is 0.885 ; it is greater than 0.5 , so it is acceptable. 
Table 10. Reliability of the questionnaire

\begin{tabular}{|c|c|c|}
\hline $\begin{array}{c}\text { Cronbach's } \\
\text { Alpha }\end{array}$ & $\begin{array}{c}\text { Cronbach's Alpha Based on } \\
\text { Standardized Items }\end{array}$ & N of Items \\
\hline 0.885 & 0.897 & 32 \\
\hline
\end{tabular}

Moreover, the questionnaire items are investigated separately. They are tested whether removing any item increasing reliability or not. Table 11 reported that the Cronbach's alpha for the overall scale of each of the factors ranged from 0.878 to 0.890 . None of the items was deleted for further analysis as Cronbach's alphas if item deleted for each of the items were lower than the respective factor's Cronbach's alpha.

Table 11. Item-Total Statistics

\begin{tabular}{|c|c|c|c|c|c|}
\hline Items & $\begin{array}{c}\text { Scale Mean } \\
\text { if Item } \\
\text { Deleted }\end{array}$ & $\begin{array}{c}\text { Scale } \\
\text { Variance if } \\
\text { Item } \\
\text { Deleted }\end{array}$ & $\begin{array}{l}\text { Corrected } \\
\text { Item-Total } \\
\text { Correlation }\end{array}$ & $\begin{array}{c}\text { Squared } \\
\text { Multiple } \\
\text { Correlation }\end{array}$ & $\begin{array}{c}\text { Cronbach's } \\
\text { Alpha if } \\
\text { Item } \\
\text { Deleted }\end{array}$ \\
\hline BI1 & 155.44 & 368.006 & 0.649 & 0.853 & 0.879 \\
\hline BI2 & 155.41 & 366.366 & 0.614 & 0.795 & 0.879 \\
\hline BI3 & 155.31 & 371.024 & 0.562 & 0.778 & 0.880 \\
\hline CSE1 & 155.79 & 365.077 & 0.631 & 0.842 & 0.878 \\
\hline CSE2 & 156.47 & 369.242 & 0.431 & 0.569 & 0.881 \\
\hline CSE3 & 156.38 & 361.794 & 0.511 & 0.722 & 0.880 \\
\hline CSE4 & 155.59 & 369.497 & 0.553 & 0.816 & 0.880 \\
\hline EI1 & 156.51 & 365.606 & 0.451 & 0.653 & 0.881 \\
\hline EI2 & 156.89 & 369.755 & 0.398 & 0.654 & 0.882 \\
\hline EI3 & 156.56 & 370.592 & 0.386 & 0.581 & 0.882 \\
\hline PBC1 & 155.71 & 367.966 & 0.520 & 0.739 & 0.880 \\
\hline $\mathrm{PBC} 2$ & 155.69 & 372.256 & 0.382 & 0.785 & 0.882 \\
\hline PBC3 & 155.43 & 369.217 & 0.531 & 0.858 & 0.880 \\
\hline PEOU1 & 156.53 & 365.545 & 0.478 & 0.719 & 0.880 \\
\hline PEOU2 & 155.81 & 367.792 & 0.514 & 0.605 & 0.880 \\
\hline PEOU3 & 155.65 & 365.098 & 0.654 & 0.803 & 0.878 \\
\hline PEOU4 & 156.56 & 371.744 & 0.361 & 0.593 & 0.882 \\
\hline PR1 & 157.27 & 391.452 & -0.50 & 0.756 & 0.890 \\
\hline PR2 & 157.81 & 390.984 & -0.41 & 0.708 & 0.890 \\
\hline PR3 & 157.56 & 391.582 & -0.52 & 0.695 & 0.890 \\
\hline PR4 & 157.84 & 400.924 & -0.228 & 0.758 & 0.894 \\
\hline PU1 & 155.21 & 365.157 & 0.627 & 0.729 & 0.878 \\
\hline PU2 & 155.25 & 375.806 & 0.384 & 0.690 & 0.882 \\
\hline PU3 & 155.30 & 366.919 & 0.658 & 0.818 & 0.879 \\
\hline PU4 & 155.71 & 371.097 & 0.333 & 0.608 & 0.883 \\
\hline SI1 & 156.64 & 365.627 & 0.416 & 0.730 & 0.882 \\
\hline SI2 & 156.59 & 358.850 & 0.576 & 0.763 & 0.878 \\
\hline SI3 & 156.20 & 363.333 & 0.567 & 0.749 & 0.879 \\
\hline TRG1 & 156.22 & 362.214 & 0.595 & 0.763 & 0.878 \\
\hline TRG2 & 156.07 & 366.874 & 0.490 & 0,723 & N/i 0.880 \\
\hline TRG3 & 156.30 & 364.939 & 0.543 & 0.596 & 0.879 \\
\hline TRG4 & 156.04 & 367.453 & 0.550 & 0.802 & 0.880 \\
\hline
\end{tabular}

\subsection{VALIDITY ANALYSIS}

Validity means; "the extent to which a test measures what it claims to measure. It is vital for a test to be valid in order for the results to be accurately applied and interpreted" [14]. Factor analysis is a statistical method used to describe variability among observed variables in terms of fewer unobserved variables called factors. Kaiser-Meyer-Olkin measures of the sampling adequacy were indicating sufficient inter-correlations. Kaiser-Meyer-Olkin measure of the sampling adequacy was also far greater than .50 . 
$\mathrm{BI}$ is an indication of an individual's preparedness to perform a given behavior. The Bartlett test of sphericity was significant and the Kaiser-Meyer-Olkin measure of the sampling adequacy was also greater than .50 , which is 0.751 (Table 12).

PU is the degree to which a person believes that using a particular system would enhance his or her job performance. The Bartlett test of sphericity was significant and the Kaiser-Meyer-Olkin measure of the sampling adequacy was also greater than .50 , which is 0.750 (Table 12).

PEOU is the degree to which a person believes that using a particular system would be free of effort. There are four items in factor PEOU that was used in this factor analysis. The Bartlett test of sphericity was significant and the Kaiser-Meyer-Olkin measure of the sampling adequacy was also greater than .50 , which is 0.679 (Table 12).

PBC is the perceived ease or difficulty of performing the behavior. The Bartlett test of sphericity was significant and the Kaiser-Meyer-Olkin measure of the sampling adequacy was also greater than .50, which is 0.693 (Table 12).

TRG composes of four items that was used in this factor analysis. The Bartlett test of sphericity was significant and the Kaiser-Meyer-Olkin measure of the sampling adequacy was also greater than .50, which is 0.767 (Table 12).

Table 12. Kaiser Meyer Olkin value of BI

\begin{tabular}{|l|r|r|r|r|r|r|}
\hline \multicolumn{2}{|l|}{} & \multicolumn{1}{c|}{ BI } & \multicolumn{1}{c|}{ PU } & \multicolumn{1}{c|}{ PEOU } & \multicolumn{1}{c|}{ PBC } & \multicolumn{1}{c|}{ TRG } \\
\hline $\begin{array}{l}\text { Kaiser-Meyer-Olkin Measure of } \\
\text { Sampling Adequacy. }\end{array}$ & .751 & .750 & .679 & .693 & .767 \\
\hline $\begin{array}{l}\text { Bartlett's } \\
\begin{array}{l}\text { Test of } \\
\text { Sphericity }\end{array}\end{array}$ & Approx. Chi-Square & 178.838 & 140.928 & 46.171 & 94.898 & 140.928 \\
\cline { 2 - 7 } & Sig. & .000 & .000 & .000 & .000 & .000 \\
\hline
\end{tabular}

\subsection{REGRESSION ANALYSIS}

The appropriateness of the proposed model was checked by multiple regression analysis. Regression analysis includes any techniques for modelling and analysing several variables, when the focus is on the relationship between a dependent variable and one or more independent variables. More specifically, regression analysis helps us understand how the typical value of the dependent variable changes when any one of the independent variables is varied, while the other independent variables are held fixed. As shown in Table 13, all constructs that affect the main constructs were statistically significant. Also, all hypotheses were accepted (Table 14).

Table 13. Regression results of the proposed model

\begin{tabular}{|c|c|c|c|}
\hline Factor & $\mathbf{R}^{2}$ & $\begin{array}{c}\text { Adjusted } \\
\mathbf{R}^{2}\end{array}$ & $\mathbf{P}$ \\
\hline BI & -497 & -481 & -000 \\
\hline PU & .264 & .241 & -000 \\
\hline PEOU & .532 & .523 & - OOO \\
\hline PBC & .147 & .120 & -000 \\
\hline TRG & .421 & .403 & -000 \\
\hline
\end{tabular}


Table 14. Hypotheses results of the proposed model

\begin{tabular}{|c|c|c|c|c|c|c|}
\hline Factor & $\begin{array}{c}\text { Antecedents } \\
\text { Factor }\end{array}$ & Hypotheses & Result & $\boldsymbol{\beta}$ & $\mathbf{t}$ & Significance \\
\hline \multirow{3}{*}{ BI } & PU & H1 & Accepted & .321 & 3.757 & .000 \\
\cline { 2 - 7 } & PEOU & H2 & Accepted & .256 & 2.978 & .004 \\
\cline { 2 - 7 } & PBC & H3 & Accepted & .297 & 3.174 & .002 \\
\hline PU & CSE & H4 & Accepted & .451 & 4.733 & .000 \\
\hline PEOU & CSE & H5 & Accepted & .738 & 10.502 & .000 \\
\hline PBC & TRG & H6 & Accepted & .328 & 2.192 & .031 \\
\hline \multirow{3}{*}{ TRG } & SI & H7 & Accepted & .267 & 2.663 & .009 \\
\cline { 2 - 7 } & EI & H8 & Accepted & .279 & 2.800 & .006 \\
\cline { 2 - 7 } & PR & H9 & Accepted & -.388 & -4.941 & .000 \\
\hline
\end{tabular}

\section{Conclusions}

E-Government infrastructure is a combination of legal, technical, knowledge and administrative policy that are critical for the success of the e-government applications. In the literature, there are several models that analyze the users' acceptance of technology. In recent years, a great amount of study has been performed to clarify which constructs affect users' technology acceptance. While information technology offers high performance and efficiency for users, many systems are not used appropriately and adequately because of the users' adoption problems such as unawareness. The study aims to predict the factors which effect e-government service usage and a model is developed to achieve this. It provides some references to understand citizens' acceptance level of e-government services. The proposed research model is based on TAM and TPB. The hypotheses were developed in accordance with the proposed model. A literature survey was conducted to gain information about the current e-government technology acceptance the research in the world. The questionnaire was prepared with the C\#.net language. The questionnaire is composed of nine demographic questions and 32 items. These questions serve the purposes to see how closely the sample replicates the known population. To sum up the demographic information, 100 responders participated to the study. Majority of participants were between the ages of 21-30. About $\% 65$ of the participants graduated from university. Most of the participants work in private sector. The appropriateness of the proposed model is checked by multiple regression analysis. The study shows that the perceived usefulness, perceived ease of use and perceived behavioural control affect citizens' intention to use e-government services. Results show that all items satisfy the reliability conditions and the regression analysis results showed that all hypotheses were supported.

Government policy makers, government agencies and system developers can benefit from the results of this study. Also, this study could provide some valuable references to understand citizens' acceptance level of technology and e-government services.

According to the results, citizens' intention to use e-government services is influenced by perceived usefulness, perceived ease of use and perceived behavioural control. More information and publicity about the usefulness of e-government services can be provided by the government agencies. While designing an e-government web page, system developers should take care to it easy to use. In addition, usability tests must be performed by system developers. 
Moreover, the regression analysis results show that trust to the government is a predictor of citizens' perceived behavioural control about e-government service usage. Therefore, in order to improve the perceived behavioural control of using the e-government web sites, citizens' level of trust to e-government service needs to be enhanced. On the other hand, results show that external influence and social influence significantly affect citizens' opinion about the trust to the egovernment services. In the light of the foregoing findings, government agencies may encourage the trust to the e-government by promoting e-government web pages in popular media, mass media and social media.

As it mentioned above, most of our responders have used computer and internet for seven years. On the other hand, the questionnaire was not distributed to people who do not have internet or computer usage. These constraints might lead to difficulties to generalize the findings of this study to all level of citizens. In order to assess technology acceptance of citizens, the questionnaire will be distributed to all user groups. The answers of people who are not familiar with the internet and computer will be collected After that, results will be compared. Moreover, in this study only a small size of sample was collected. The total number of usable sample will be increase. For further study, new data will be collected from a new participant group to test the hypothesis of the proposed model.

\section{REFERENCES}

[1] Archetypon, "e-government Unit" (n.d.) . http://egov.archetypon.com/faqPage.html\#1 , [Accessed 30.9.2009]

[2] A. Arifoğlu. e-Dönüşüm yol haritası, dünya, Türkiye. Ankara: SAS Bilişim, 2004.

[3] F.D., Davis. "Perceived usefulness, perceived ease of use, and user acceptance of information technology". MIS Quarterly, vol. 13 (3), pp. 319-342, 1989.

[4] V. Venkatesh, M.G. Morris, G.B. Davis and F. D. Davis. "User acceptance of information technology: toward a unified view”. MIS Quarterly, vol. 27 (3), pp.425-478, 2003.

[5] G. C. Moore and I. Benbasat. "Development of an instrument to measure the perceptions of adopting an information technology innovation", Information Systems Research, vol. 2(3), pp.192-222, 1991

[6] J. Fu, C. K. Farn and W. Chao. "Acceptance of electronic tax filing: a study of taxpayer intentions". Information \& Management, vol.43, pp.109-126, 2006.

[7] S.-Y. Hung, C.-M. Chang and T.-J. Yu. "Determinants of user acceptance of the e-Government services: The case of online tax filing and payment system". Government Information Quarterly, vol. 23, pp.97-122, 2009.

[8] M. Marvine Hamner and R-U-R Qazi. "Expanding the technology acceptance model to examine personal computing technology utilization in government agencies in developing countries". Government Information Quarterly, vol. 26, pp. 128-136, 2009.

[9] D. V. Dimitrova and Y-C. Chen. "Profiling the adopters of e-government information and services: The influence of psychological characteristics, civic mindedness, and information channels". Social Science Computer Review, vol. 24, pp. 172-188, 2006.

[10] T. Ramayah, M. Y. Yusoff, N. Jamaludin, A. Ibrahim. "Applying the theory of planned behavior (tpb) to predict internet tax filing intentions". International Journal of Management, vol. 26 (2), pp. $272-$ 284, 2009.

[11] B. Gupta, S. Dasgupta and A. Gupta. "Adoption of ICT in a government organization in a developing country: An empirical study". Strategic Information Systems, vol. 17 (2), pp.140-154, 2008.

[12] W. Money and A. Turner. "Application of the technology acceptance model to a knowledge management system". Proceedings of the 37th Hawaii International Conference on System Sciences, 2004.

[13] I. Ajzen. Attitudes, personality and behavior. Chicago, IL: Dorsey Press, 1988.

[14] L. Crocker and J. Algina. Introduction to classical and modern test theory. NEW YORK: CBS, 1986.

[15] U. Sekaran. Research methods for business: a skill-building approach. 4th Edition, John Wiley \& Sons, New York, 2003. 


\section{APPENDIX: QUESTIONNAIRE ITEMS}

\section{Behavioural Intention (BI)}

1- I intend to use e-government web sites in the future.

2- It is likely that I will use e-government web sites in the future.

3- To the extent possible, I would try to use e-government web sites in the future.

\section{Computer Self Efficacy (CSE)}

1- I feel confident using e-government web sites if there was no one around to tell me what to do.

2- I feel confident using e-government web sites if I had just the built-in help facility for assistance.

3- I feel confident using e-government web sites if I had used similar web sites before this one to do the same job.

4- I feel comfortable e-government web sites on my own.

\section{External Influence (EI)}

1- I read/saw reports that using e-government web sites was a good way of governmental work.

2- The popular press depicted a positive sentiment for using e-government web sites.

3- Mass media reports influenced me to try out e-government web sites.

\section{Perceived Behaviour Control (PBC)}

1- I had the resources to make use of the e-government web sites.

2- I had the knowledge to make use of the e-government web sites.

3- I had the ability to make use of the e-government web sites.

\section{Perceived Ease of Use (PEOU)}

1- Getting the information that I want from e-government web site is easy.

2- It is easy for me to complete a transaction through an e-government website.

3- My interaction with e-government web sites is clear and understandable.

4- It is easy for me to become skillful at using the e-government web sites.

\section{Perceived Risk (PR)}

1- Use of e-government web sites may cause my personal information to be stolen.

2- I will feel uneasy psychologically if I use e-government web sites.

3- I do not think it is safe to use e-government web sites because of the privacy and security concerns.

4- All things considered, I think I would be making a mistake if I used the e-government web sites for my governmental work.

\section{Perceived Usefulness (PU)}

1- Using e-government web sites enables me to accomplish tasks more quickly.

2- Using e-government web sites can cut traveling expense.

3- Using e-government web sites can lower traveling and queuing time.

4- Using e-government web sites enables me to do business with government any time, not limited to regular business hours.

\section{Social Influence (SI)}

1- People who influence my behaviour will think that I should use e-government web sites.

2- People I know think that using e-government web sites is a good idea.

3- People whose opinions I valued preferred that I use e-government web sites.

\section{Trust to government (TRG)}

1- e-government web sites can be trusted to carry out online transactions faithfully.

2- I believe that e-government web sites are trustworthy.

3- I trust e-government web sites to keep my best interest in mind.

4- Even if not monitored, I'd trust e-government websites to do job right. 